ELIZABETH ANDERSON

\title{
ETHICAL ASSUMPTIONS IN ECONOMIC THEORY: SOME LESSONS FROM THE HISTORY OF CREDIT AND BANKRUPTCY
}

Accepted 15 July 2004

\begin{abstract}
This paper evaluates the economic assumptions of economic theory via an examination of the capitalist transformation of creditor-debtor relations in the 18th century. This transformation enabled masses of people to obtain credit without moral opprobrium or social subordination. Classical 18th century economics had the ethical concepts to appreciate these facts. Ironically, contemporary economic theory cannot. I trace this fault to its abstract representations of freedom, efficiency, and markets. The virtues of capitalism lie in the concrete social relations and social meanings through which capital and commodities are exchanged. Contrary to laissez faire capitalism, the conditions for sustaining these concrete capitalist formations require limits on freedom of contract and the scope of private property rights.
\end{abstract}

KEY WORDS: bankruptcy, capitalism, credit, economics, libertarianism, property rights

\section{CAPitAlism as an AbStraction: The Formalism OF ECONOMIC THEORY}

A central function of economic theory is to explain and evaluate the operations of capitalist economies. Is economic theory up to the evaluative task? To perform this task, its concepts must be able to adequately represent the virtues and vices of capitalism. That is, when these concepts are applied to actual capitalist practices and institutions, they must be able to discriminate between their better and worse features, and enable measurement of the degree to which they satisfy normative requirements.

Most critics of the normative framework of economic theory fault it for failing to recognize the vices of capitalism - for example, its inability to evaluate the inequality that capitalism generates. My thesis turns this critique on its head: the assumptions of economic theory fail to represent some of the virtues of capitalism. They fail to grasp some ways in which capitalism advanced freedom and equality. One way was by transforming the social relations of creditors to debtors. This enabled millions of people to obtain credit without having to give up their personal independence to or demean themselves before their creditors.

I shall argue that the ethical assumptions of economic theory cannot represent this transformation as virtuous, because they are too abstract.

Ethical Theory and Moral Practice 7: 347-360, 2004.

(c) 2004 Kluwer Academic Publishers. Printed in the Netherlands. 
The kinds of freedom and equality that fundamentally matter, and that capitalism expanded, are embodied in concrete social relations governed by specific legal constraints and social norms. Freedom involves, at least, freedom from bondage to others. Equality involves a kind of social standing before others, premised on terms of interaction consistent with the dignity of both parties. Economic theory represents freedom and equality in abstraction from these concrete social relations. It represents freedom as freedom of contract - freedom to alienate any property to another, including property in the self. Equality is formal equality - the equal right to enter contracts and own property. These abstractions do not distinguish between free contracts and contracts into bondage, or between agreements reached by self-debasement or a dignified offer.

It follows that the virtues of capitalism cannot be deduced from the bare forms of private property and voluntary exchange. They depend on conditions not represented in the standard economic arguments for capitalism. These conditions often require constraints on the scope of freedom of contract and property rights, against the laissez faire ideal.

\section{Three Moral ECONOMies of DebT}

Let us explore the development of creditor-debtor relations as our window into the moral transformations brought about by capitalism in Europe and America. At the emergence of the transatlantic economy of Europe and her American colonies in the 17th and 18th centuries, three moral economies of debt were in play: Christian, aristocratic, and capitalist.

Within the Christian ethic, credit had long been a morally perilous institution. For centuries, the Catholic Church had prohibited, on Biblical authority (Deut. 23:19), the charging of interest among Christians. The task of doing so was assigned to Jews, who were thereby constituted as social pariahs (Nelson, 1969, pp. 6, 14). Although the Protestant Reformation had relaxed the rules against interest (Nelson, 1969, pp. 67, 78-83), and interest had become indispensable to the transatlantic economy, the granting of loans among Christians without interest was still commonplace. By the 18th century, the main moral onus of credit rested with debtors. Indebtedness carried a moral taint, suggesting profligacy and vanity. Failure to pay off one's debts was a sin. Debtors in default could be bound over in service to their creditors, or thrown into debtors' prison. These punishments were mentioned in the Bible (e.g., 2 Kings 4:1; Matthew 18:25), and widely practiced in Europe and the Americas. ${ }^{1}$

\footnotetext{
${ }^{1}$ This is not to say that the claimed Biblical warrant for such harsh treatment of debtors is sound. The Bible consistently praises mercy toward debtors and calls for the cancellation
} 
The aristocratic ethic viewed indebtedness with greater indulgence. A lifestyle befitting someone of superior social status could often be sustained only on credit. More importantly, aristocrats and gentlemen used credit a means of binding social inferiors to them. Servants, peasants, and other social inferiors would often come to them, pleading for loans. They would record such loans in book accounts, which had open-ended terms and carried no interest (Mann, 2002, p. 10). The lack of interest did not mean that creditors exacted no price from their debtors in return for a loan. The price of credit was subjection to one's creditor (Wood, 1993, pp. 68-73). This entailed acknowledgment of an inferior social status. One needed to defer to one's creditor, humble oneself before him. In the American colonies, the leading gentlemen were responsible for raising militias for collective defense. They summoned the militia from among their debtors, who were obliged to recognize their creditors as their military commanders (Wood, 1993, p. 74). If debtors became insolvent, they could be bound over in service to their creditor (Mann, 2002, p. 79). Debtors' prison put insolvent debtors at the mercy of their creditors. Debtors in default were put in prison via a civil (not a criminal) process, and could be held there indefinitely at the will of their creditors. The state provided imprisoned debtors no food, clothing, medical treatment, or heat. They had to beg for subsistence, and many died (Mann, 2002, pp. 81, 87-88).

During the 18th century, a capitalist ethic of debt challenged both the Christian and the aristocratic ethics. Consider first the Christian ethic. Moral doubts about charging interest were dealt a death knell by the ubiquity of interest in the emerging capitalist order. More significantly, moral opprobrium can hardly attach to a condition necessary for the pursuit of nearly any occupation. In the transatlantic economy, debt had become such a condition. Long-distance commerce entailed a temporal gap between an American merchant's contract to purchase European manufactured goods and his acquisition of the revenue needed to pay off his wholesaler. The gap was covered by a bill of exchange, which constituted a debt until it was presented for payment in coin. American farmers, producing cash crops for the European market, could no less avoid debt. They required an advance from European merchants for seeds, tools, and food until they could deliver their crops in payment. Since credit was essential to production, it could no longer be regarded as a sign of prodigality and sloth. As Adam Smith observed, "Among borrowers ... the number of the frugal and industrious surpasses considerably that of the prodigal and idle" (Smith, 1974 [1776], pp. 450-451).

of debts every seven years (Deut. 15; see also Lev. 25:10-28). This debtor-friendly Biblical tradition informs contemporary Christian movements for international debtor relief. See, for example, Ecumenical Steering Committee for Jubilee 2000-Zambia (1998). 
The rise of capitalism blunted the moral edge of insolvency, by raising the salience of causes of insolvency that could not be attributed to vice (Mann, 2002, pp. 46-47, 82-83). Indebted farmers could be ruined by bad weather, or a fall in the price of their crop. Indebted merchants could be ruined by sunken ships, or the default of their own debtors. Capitalist business cycles tied the fortunes of everyone together, independent of variations in their moral probity.

Capitalism posed equally grave challenges to the aristocratic ethic. The assignability of debts to distant creditors via bills of exchange fatally undermined the logic of gift and honor that grounded the aristocratic moral economy. The contract between gentleman creditor and low-born debtor traded money for personal recognition, in the form of obsequiousness and subservience. This type of compensation could be exacted only so long as creditors and debtors stood in face-to-face social relations. Debts assigned to distant and anonymous creditors could not be so easily paid in the currency of social recognition. A debtor cannot bow and scrape before a creditor hundreds or thousands of miles away, nor could an anonymous creditor bask in the glory of such a display. Economic interest, not honor, motivated the creditors to whom distant debts were assigned.

This fact undermined the motive for seeking punitive treatment of insolvent debtors. Creditors in the game for the glory could feel compensated for unpaid debts by putting their debtor at their mercy in prison. This arrangement offered no advantage to creditors motivated by profit. An imprisoned debtor could not work to pay off his debts.

Finally, the capitalist ethos generated a powerful rationale for laws enabling voluntary bankruptcy. Insolvents burdened with overwhelming debts had little incentive to work, knowing that the fruits of their labors would go to their previous creditors. Bankruptcy, by discharging unpaid debts, facilitates the reintegration of insolvents into the economy, rather than leaving their talents and energies to waste (Mann, 2002, p. 58). It is also economically superior to bondage. A bonded debtor would be unlikely to be put to his most economically productive uses, if he was prevented from seeking other employers.

\section{Why the Capitalist Moral Economy of DebT was AN ETHICAL ADVANCE}

I shall now argue that the triumph of the capitalist ethic of debt over the aristocratic and Christian ethics greatly advanced freedom and equality.

By freedom, I mean personal independence: freedom from bondage, from others' dominion. This was the view of freedom held by the classical economists Smith and Condorcet (Rothschild, 2001, pp. 22, 23, 70, 202). 
Condorcet defined liberty as "not being dependent ... on the whims of a man": "a man is called free if he is not subject in any of his private actions to the arbitrary will of an individual" (Rothschild, 2001, p. 202). Smith commended capitalist manufacturing and commerce over aristocratic agriculture for promoting the personal independence of workers. Servants, retainers, and tenants were dependent on and subservient to their landlords. By contrast, "commerce and manufactures" improved the "liberty and security of individuals" by releasing them from "servile dependency on their superiors." "This ... is by far the most important of their effects" (Smith, 1974 [1776], p. 508).

The abolition of debtors' prison, bondage, and debt peonage amounts to liberation from one's creditors. This constituted a vast increase in human freedom. Bankruptcy laws advanced freedom even more. Discharge enables insolvent debtors to escape permanent receivership. More generally, credit can be obtained without submission. No one today imagines that obtaining a mortgage obliges him to join a militia run by the president of their bank.

By equality, I mean a social standing whereby one makes claims without casting them either as orders to inferiors, or as supplications of superiors. In the era of interest-free account books, people had to beg for loans from superiors. They got credit by flattering their creditors' pride. In a wholly capitalist transaction, people get what they want by appealing to others' interest, not their pride. This enables both sides to preserve their dignity. Adam Smith stressed this point in his famous remarks on the human tendency "to truck, barter, and exchange":

When an animal wants to obtain something ... it has no other means of persuasion but to gain the favor of those whose services it requires. A puppy fawns upon its dam, and a spaniel endeavors by a thousand attractions to engage the attention of his master who is at dinner, when it wants to be fed by him. Man sometimes uses the same arts with his brethren, and ... endeavours by every servile and fawning attention to obtain their good will. ... But man has almost constant occasion for the help of his brethren, and it is in vain for him to expect it from their benevolence only. He will be more likely to prevail if he can ... show them that it is for their own advantage to do for him what he requires of them .... It is not from the benevolence of the butcher, the brewer, or the baker that we expect our dinner, but from their regard to their own interest. We address ourselves, not to their humanity, but to their self-love .... Nobody but a beggar chooses to depend chiefly upon the benevolence of his fellow-citizens (Smith, 1974 [1776], pp. 118-119). ${ }^{2}$

Smith reminds us that dependence on others' good will comes at a steep price in personal dignity, which we avoid when we interact with them on the basis of mutual self-interest.

The ability of ordinary people to obtain credit with dignity reflects a larger transformation in the moral economy of social status made possible

\footnotetext{
${ }^{2}$ I thank Stephen Darwall for pointing out the significance of this passage to me.
} 
by capitalism. The aristocratic moral economy of debt was enmeshed in the logic of gift rather than commercial exchange. Credit was seen as a form of charity to the needy and dependent (Wood, 1993, p.140). Honor redounds to whoever bestows such charity, setting the gift-giver on a higher social plane than the recipient. Recipients of unreciprocated gifts are obliged to honor and obey their benefactors. Because gift-giving bestows honor, it is an object of competition. This practice presupposes a moral economy of social status as zero-sum, a form of positional competition. One person's honor is attained at the expense of another's debasement.

By contrast, exchange on the basis of mutual self-interest can preserve the independence and dignity of both parties. Capitalism, by enabling ordinary people to make a living without depending on noblesse oblige, thereby transformed the moral economy of social standing to a more egalitarian and potentially universalizable footing. Dignity is not a competitive good. It is universalizable. Expressing respect to another in a mutually self-interested exchange need not come at the cost of one's own dignity.

\section{NORMATIVE ASSUMPTIONS OF ECONOMIC THEORY: LIBERTARIAN AND PARETIAN SCHOOLS}

Thus, the transition to a capitalist ethic of debt increased freedom and equality. The classical economists had the ethical concepts needed to commend this transformation. Would economic theory today approve of it? Consider the two main schools of contemporary capitalist economic thought. First, there is libertarian political economy, including such figures as Friedrich Hayek (1960; 1976), Robert Nozick (1974), and Richard Epstein (1998; 1995). This school takes freedom to be the central good. Second, there is the school of Paretian welfare economics, founded by Vilfredo Pareto (1971), and standardized in introductory economics textbooks. This school takes efficiency to be the central good.

The libertarian and Paretian schools of thought share a conception of capitalism based on abstract notions of private property and free markets: the more property is held in private hands, and the more freely it can be traded without state interference, the more capitalist it is. Both schools argue that capitalism is the best economic system, on the basis of abstract arguments about the nature of private property and market transactions. Privatization of productive resources encourages improvements and hence raises productivity. State-imposed limitations on contracts restrict the freedom of the contracting parties to trade one thing for another. Setting aside monopolies, externalities and information asymmetries, such limitations cannot be Pareto efficient. For if each of the parties prefers the other's possession to that which they own, then both sides could gain if they were allowed to trade. 
There is an intimate connection between the libertarian and Paretian efficiency schools of thought. Although libertarians identify individual freedom with property rights, this representation shows us only one side of the coin. The essence of a private property right is not the individual's freedom to use the item in question, since the individual also enjoys this right if the item is in the commons. It is rather the use of state power to restrict the freedom of other people to use it. A libertarian system can justify this restriction of freedom only by arguing that the freedom secured to the owner is more valuable than the freedom denied to others (Sterba, 1994; Taylor, 1985). In practice, libertarians such as Nozick appeal to the classic Pareto improvement criterion to justify the restrictions on liberty entailed by private property (Nozick, 1974, p. 176-177). They thereby assume that a restriction of liberty can be justified only if it makes no one worse off in terms of welfare (not liberty) (DeLong, 2003).

Libertarians and Paretians differ over the determination of the initial distribution of property. Libertarians believe that there are natural laws of just appropriation that determine the initial distribution of property. Paretians allow that the state could determine the initial distribution of property. Both agree that after the initial distribution, free markets should determine subsequent allocations (leaving aside externalities, monopolies, and information asymmetries). Libertarians and Paretians thus share a proceduralist conception of justice. They deny that the identity of the owners matters to the justice of a property distribution.

\section{Libertarian Evaluation of the Capitalist Ethic of DebT}

Consider now whether libertarians would approve of the transition from an aristocratic to a capitalist ethic of debt. Recall the critical legal features of this transition: (1) abolition of debt peonage; (2) abolition of bondage and debtors' prison; (3) discharge of a bankrupt's debts, at the instigation of the debtor. The transition also involved cultural changes in the motivational appeal and meaning of debtor-creditor interaction, from flattery to selfinterest, from subordination to equality.

Libertarians would reject the three legal changes as violations of natural property rights. Debt peonage arises from a contract in which the debtor agrees to remain in the exclusive service of his creditor until the loan is paid off. Notoriously, such contracts are rigged to keep the debtor in permanent subjection, unable to bid for higher wages by threatening to take up another employer's superior offer. Yet libertarians hold that the creditor has a right to full enforcement of the terms of such contracts (Nozick, 1974, p. 331). State abolition of debt peonage is an unjust violation of rights to property and freedom of contract. Similar considerations apply to the abolition of 
bondage and imprisonment as remedies for default. A pure system of free contract could not question the voluntary acceptance of these remedies. Most importantly, discharge of the bankrupt's debts violates the creditor's supposed natural rights to the debtor's property.

The case of bankruptcy puts libertarians in a difficult position. If they insist on their system of natural liberty, many state constructions of private property, essential to modern capitalism, cannot be justified. Bankruptcy is just one example. The limited liability corporation is another. A group or artificial person cannot escape liabilities to which its individual members would be subject. Intellectual property is another. Patents and copyrights, unlike natural property rights, expire. Patent law also denies independent inventors the right to exploit their inventions, if they are not the first to file for a patent. Negligence rules, as opposed to strict liability in torts, are another (Epstein, 1975). Many of the enabling laws of modern capitalism, from the laws of partnerships, incorporation, securities and banking, to the uniform commercial code, are not merely state enforcements of natural property rights.

Libertarianism also endorses systems of unfree labor, provided they were established contractually rather than by birth or conquest. It has no objection to the company towns of the past, in which workers were paid in scrip that could be redeemed only at company stores. In one such town, Pullman, Illinois, workers had to sign leases for company-owned housing, whereby the company owner dictated details of their home lives. As owner of the town, Pullman appointed himself mayor and forbad the construction of any churches but his own (Walzer, 1983, pp. 295-297). Since these arrangements were contractual, libertarians have no objection to them. But this isn't capitalism. It's feudalism.

It is futile to argue that free market competition would eventually enable people to leave these towns and build freer lives. Once it is conceded that such arrangements do not enable people to lead free and dignified lives as equals, there is no point in waiting for market forces to end these anticompetitive arrangements, when legal means can directly abolish them. Perhaps some libertarians would concede this point. This is to accept that some rights are so deeply connected to the self that they cannot be alienated without compromising the individual's standing as a free and equal person (Radin, 1982; 1987). To accept market-inalienable rights leads libertarianism away from abstract freedom of contract. It requires abandonment of neutrality about who owns which items of property. Market-inalienable rights suppose that it is vital that each individual permanently retain certain liberty rights over her own person. To accept this is also to abandon the monetized version of the Pareto-improvement test for a just allocation of property. Willingness-to-pay is not a valid measure of the value of a right being possessed by a particular person. Rather, given that all property rights 
in a good secure a liberty for some by coercively depriving others of liberty to use that good, the relative value of these mutually exclusive liberties depends on whether they realize the freedom (personal independence) and equal standing of persons.

Once we accept that a person's claim to a property right depends on whether her possession of that right promotes freedom and equality, the way is open for additional regulations of trade. There can be no objection on grounds of natural rights to the market-restricting laws made in capitalist countries to protect the dignity of persons, including antidiscrimination laws, minimum wage and maximum hours laws, and so forth.

Capitalism enabled the mass of people to see themselves as entitled to respect and dignity in their commercial relations. This is the great cultural transformation marked by the transition from an aristocratic to a capitalistic ethic of credit. Once people see themselves as so entitled, they make use of the law to secure and extend these entitlements. The legal constraints on contract ensure that the workings of the market do not backslide into feudalism, that capitalism does not undermine its own cultural achievements. The form of capitalism they bring about is not libertarian laissez faire, but rather capitalism as we know it in the advanced democracies.

\section{Paretian Evaluation of the Capitalist Ethic of DebT}

How should Paretian welfare economists judge the transition to a capitalist ethic of debt? They should have no principled objection to the discharge of a bankrupt's debts. When business cycles force many individuals and firms to go bankrupt at the same time, discharge is a critical tool for avoiding a permanently stagnant economy.

However, other aspects of the capitalist legal transformation distribute property rights in ways that forbid contractual reallocation. The Coase Theorem (Coase, 1988) explains why this is inefficient. It states that the allocation of property rights makes no difference to efficiency, as long as the parties are free to cheaply bargain their way to an alternative allocation. The Coase Theorem can be applied to the prohibition of debt peonage and debtors' prison. If a debt peon's labor would be more productive to another employer than to his master, he could persuade the master to release him from peonage by signing over part of his future wages. But if he can't persuade the master to release him, then it is more efficient to keep him a peon. So peonage should be permitted. Similarly, if a debtor is worth more to his creditors working than in prison, they will agree to release him. Creditors who want a monetary return from their debtor will offer to pay those who prefer to take their pound of flesh to agree to release the debtor from prison. If the payment is not enough to persuade, then 
it is more efficient to keep the debtor in jail. So debtors' prison should also be permitted, as long as creditors are free to negotiate their way to an alternative. The Coase Theorem entails that the aristocratic system of credit was efficient after all. ${ }^{3}$

By contrast, inefficiencies are built into modern creditor-debtor law. If peonage contracts are forbidden, then presumably some people will be denied credit who might have obtained it under such terms. This denies both creditor and debtor a bargain that would supposedly be to the advantage of both. The Paretian economist should oppose the transition from an aristocratic to a capitalist ethic of debt as inefficient.

Against this reasoning, I would argue that classical economics has a better case for the superior efficiency of the capitalist order. This argument insists that the creditor-debtor relationship should be regarded as purely commercial, not a matter of honor. It is a sophisticated attempt to persuade people to see the stakes differently. Both dignitary and pecuniary interests are at stake in creditor-debtor relations. Under the aristocratic system, dignity is measured in terms of honor, a positional good. From a dignitary perspective, interactions benefit one party at the expense of the other. Moreover, to maintain the honor-based system, all its participants must suffer in pecuniary terms. The result is an economically stagnant society in which only the upper classes enjoy dignity. Under the capitalist system, dignity is measured in terms of respect, a nonpositional, universalizable good. Debtor-creditor interactions can proceed on a basis of mutual respect. Capitalist laws, by freeing debtors to pursue the highest pecuniary return on their labor, enable everyone to gain in monetary terms. The result is a prosperous society in which everyone can enjoy dignity.

The advantages of the latter society are obvious. To the aristocrat, still jealous of his honor, it may be asked: why should the coercive power of the state be deployed to underwrite a system of laws catering to the sense of honor, when this comes at such great cost to everyone's prosperity and to most people's dignity? It is unreasonable to expect others to accept a moral economy of dignity like this. This argument does not take preferences as given. It argues that some economies of dignity are better able to satisfy everyone than others. This is a reason to change preferences.

\footnotetext{
${ }^{3}$ Considerations of efficient breach do not defeat this conclusion. Paretians hold that the proper remedy for breach of contract is not specific performance, but compensation of the injured party for damages. See, e.g., Posner (1973, p. 88). They assume that damages for breach can be measured in terms of the market value of the injured party's losses. But aristocratic preferences resisted monetization, because they aimed to ensure that credit circulated in a moral economy of honor rather than pure profit. If we take the Paretian logic of given preferences seriously, we cannot assume that honorific damages can always be monetized.
} 


\section{LESSONS FOR ECONOMICS TODAY}

I want to draw four lessons from the capitalist transformation of creditordebtor relations. They concern (1) the normative framework of economics; (2) the representation of capitalism; (3) the cultural significance of capitalist transformation; and (4) implications for international economics.

\subsection{The Normative Framework of Economics}

I have argued that the normative framework of the classical economists Smith and Condorcet, is superior to that of neoclassical economics and libertarians. The classical economists had superior conceptions of freedom and equality, which are better able to grasp the specific virtues of capitalism.

Contemporary economic theory cannot represent these virtues because it is too abstract. Economic theory represents capitalist causal forces as operating through unfettered free market exchanges. Their virtue consists in the satisfaction of given preferences, or their expression of free choice. These causal forces and virtues are represented in ways that abstract from the content of the preferences, the terms of the contracts, the identities of the parties, and the social meanings of their interactions. This abstraction prevents contemporary economic theory from distinguishing a loan extended within an aristocratic moral economy of debt from one extended within a capitalist moral economy of debt. This distinction matters enormously for the freedom, equality, and dignity of the parties to a contract. To represent the specific virtues of capitalist transactions, freedom and equality must be understood in terms of the concrete social relations of the contracting parties during and after the exchange. A contract grounded in begging and selfdebasement is not a contract among equals. A contract whose terms or remedies involve bondage or servitude does not realize the freedom of the parties.

This is a problem with the powers of neoclassical economic theory to represent morally critical features of capitalism, and of economic systems more generally. A conceptual framework that measures welfare only in purely formal terms of preference satisfaction, or income and wealth, does not discriminate between contracts that, from the point of view of the freedom and dignity of the contractors, have very different values. This is not an inherent infirmity of economics as such, but only of the dominant strain of Paretian welfare economics. Alternative systems of measuring welfare, such as the capabilities approach of Amartya Sen (1985), could incorporate such important considerations as whether the contracting parties live at the mercy of their creditors or whether they can bargain for fair terms with dignity. ${ }^{4}$

\footnotetext{
${ }^{4}$ In the capabilities approach, multiple dimensions of welfare are concretely defined in terms of functionings, such as literacy, mobility, nutritional status, and the ability to appear
} 


\subsection{The Representation of Capitalism}

Contemporary economic theory represents capitalist markets as a natural kind, governed by autonomous laws operating independently of the state. This representation assumes that there is some scientific, nonpolitical way to distinguish the domain of the market from the state, "natural" property rights from "artificial" state intervention. But we have seen that capitalism requires numerous artificial property rights. If the state pervasively constitutes the parameters of the market, then many state actions labeled "interference" in the market, such as labor laws, are better represented as the constitution of artificial property rights. Many can be justified in the same normative framework that displays the virtues of bankruptcy laws. To preserve the substantive values of freedom and equality prized by the classical economists, some of these property rights must be inalienable. If bankruptcy law is part of capitalism, then the regulatory laws designed to protect the freedom and equality of workers, consumers, and investors are also part of capitalism, not an "interference" in its operations.

\subsection{The Cultural Significance of Capitalist Transformation}

Capitalism does not operate only through contractual exchanges, taking preferences and laws as given. It changes preferences and laws. The expansion of markets gave rise to a capitalist class, more interested in pecuniary gain than honor or Christian virtue, who successfully demanded changes in the legal and social norms governing credit. These changes wrested the control and meanings of credit from aristocrats and clerics. Credit no longer circulated within the sphere of contests for honor, but within the sphere of contests for profit. This changed the self-understandings and hence the preferences of creditors and debtors.

In stressing the class-based origins of the capitalist transformation of credit, I want to emphasize that the extension of its benefits to wider classes of people was not the automatic result of the autonomous workings of markets. It was the product of protracted political action. The first bankruptcy laws in Britain and the United States limited eligibility for bankruptcy to individuals engaged in commercial occupations (Mann, 2002, pp. 207-208, 222). But once the demoralization of insolvency based on an appreciation of business cycles was invoked to allow wealthy capitalists off the hook, it was only a matter of time before less privileged classes would come to understand their predicament in the same terms and demand bankruptcy protection for themselves. This isn't laissez faire. It's the popular use of

in public without shame. Capabilities are then defined as freedoms or effective opportunities to attain vectors of functionings. 
state power to extend the privileges enjoyed by capitalists to everyone else.

Such preference changes, being endogenous to capitalist markets, are as much a part of the dynamic of capitalism as market exchange. The result of these changes in Western Europe was social democracy. This was not a repudiation of capitalism, but a fulfillment of the presuppositions of capitalist market exchange that Smith and Condorcet championed. It follows that abstract laissez faire is but one (archaic) variant of capitalism, not its ideal form. Social democracy is another variant. Let us grant that, in the post-Cold War era (if it was not already obvious decades before), capitalism is the only viable form of economic organization open to countries in the developed and developing worlds. This fact implies nothing about which of many possible capitalist paths any country should follow. It acknowledges the folly of comprehensive state economic planning and ownership of the means of production, the injustice of suppressing private entrepreneurship, and the centrality of competitive market exchange, including international trade, to any country's prospects for development. But it takes no sides between Hong Kong and Sweden.

\subsection{Implications for International Economics}

The use of democratic powers to extend the privileges enjoyed by capitalists to everyone else is still under way. Millions of people across the world are trying to extend capitalist privileges to themselves, by such extralegal means as squatting. Such actions violate the tenets of laissez faire capitalism, which demands strict enforcement of private property rights. But they are part of the capitalist dynamic, as the Peruvian economist Hernando de Soto argues $(1989 ; 2000)$. Contemporary movements for the relief of debts owed by developing nations manifest the same dynamic on an international scale. If bankruptcy should be made available to individuals, it should also be made available to countries.

When people enlist state power to escape oppressive contractual relations and reformulate the rules of private property in ways that better comport with their dignity, equality, and freedom, such movements should be seen as realizing the promise of capitalism, not as violating its essence. To see this, we must step out of the formalism of economic theory and represent economic systems in terms of their import for substantive social relations of freedom and equality.

\section{ACKNOWLEDGMENTS}

I thank Carl-Henric Grenholm and the participants in the 2003 Societas Ethica conference for their generous comments. 


\section{REFERENCES}

Coase, R.H., The Problem of Social Cost, in R. Coase (ed.), The Firm, the Market, and the Law. Chicago: University of Chicago Press, 1988, pp. 95-156.

DeLong, B., Utility, Stacking the Deck, and Original Appropriation, The SemiDaily Journal of Economist Brad DeLong. http://www.j-bradford-delong.net/movable_ type/2003_archives/001778.html (retrieved on 10 October 2003).

de Soto, H., The Other Path: The Economic Answer to Terrorism. New York: Basic Books, 1989.

de Soto, H., The Mystery of Capital: Why Capitalism Triumphs in the West and Fails Everywhere Else. New York: Basic Books, 2000.

Ecumenical Steering Committee for Jubilee 2000-Zambia, Joint Pastoral Letter on International Debt, 1998. http://www.jubilee2000uk.org/jubilee2000/news/zambia0411.html (retrieved on 10 October 2003).

Epstein, R.A., A Theory of Strict Liability, Journal of Legal Studies 2 (1975), pp. 151.

Epstein, R.A., Simple Rules for a Complex World. Cambridge, MA: Harvard University Press, 1995.

Epstein, R.A., Principles for a Free Society. Reading, MA: Perseus Books, 1998.

Hayek, F.A., Law, Legislation, and Liberty. Chicago: University of Chicago Press, 1976.

Hayek, F.A., The Constitution of Liberty. Chicago: University of Chicago Press, 1960.

Mann, B.H., Republic of Debtors: Bankruptcy in the Age of American Independence. Cambridge, MA: Harvard University Press, 2002.

Nelson, B., The Idea of Usury: From Tribal Brotherhood to Universal Otherhood, Edition No. 2, enlarged. Chicago: University of Chicago Press, 1969.

Nozick, R., Anarchy, State, and Utopia. New York: Basic Books, 1974.

Pareto, V., Manual of Political Economy. New York: A. M. Kelley, 1971.

Posner, R.A., Economic Analysis of Law. Boston: Little, Brown, 1973.

Radin, M.J., Property and Personhood, Stanford Law Review 34 (1982), pp. 957-1015.

Radin, M.J., Market Inalienability, Harvard Law Review 100 (1987), pp.1849-937.

Rothschild, E., Economic Sentiments: Adam Smith, Condorcet, and the Enlightenment. Cambridge, MA: Harvard University Press, 2001.

Sen, A., Commodities and Capabilities. Amsterdam: North-Holland, 1985.

Smith, A., The Wealth of Nations. New York: Penguin Books, 1974.

Sterba, J., From Liberty to Equality, in James Sterba (ed.), Morality in Practice. Belmont, CA: Wadsworth, 1994, pp. 55-60.

Taylor, C., What's Wrong with Negative Liberty? in C. Taylor (ed.), Philosophy and the Human Sciences. Cambridge: Cambridge University Press, 1985, pp. 211-229.

Walzer, M., Spheres of Justice. New York: Basic Books, 1983.

Wood, G., The Radicalism of the American Revolution. New York: Vintage Press, 1993.

Department of Philosophy

University of Michigan

2239 Angell Hall 1003, 435 S. State St.

Ann Arbor, MI 48109-1003

E-mail: eandersn@umich.edu 